\title{
Pre-School Science Education: The Development and Evaluation of Science Teaching Materials
}

\author{
Dr. Zeynep Aksan \\ Turkey \\ E-mail: zeynep.axan@gmail.com \\ Assoc. Prof. Dilek Çelikler \\ Department of Science Education Samsun, Turkey \\ Ondokuz Mayıs University, Faculty of Education \\ E-mail: dilekc@omu.edu.tr
}

Received: Jan. 14, 2018 Accepted: Feb. 14, 2018 Published: February 14, 2018

doi:10.5296/jse.v8i1.12482 URL: https://doi.org/10.5296/jse.v8i1.12482

\begin{abstract}
It has been aimed with this study that the pre-school teaching candidates develop the science teaching materials as to use in teaching the science subjects, that the factors that the teaching candidates pay attention to develop the teaching material and the contribution of teaching material development process to them are determined. The study was conducted with the participation of 54 third-year undergraduate students majoring in Preschool Teaching. Teaching materials prepared by prospective teachers were examined using descriptive analysis. It was found that prospective teachers took care to build colorful and fun materials designed to attract children's attention, using easy to source materials. The use of teaching materials in science education is important for drawing and retaining students' attention, for making science fun, and for achieving long-term and meaningful learning.
\end{abstract}

Keywords: Teaching material, pre-school, prospective teacher, science education. 


\section{Introduction}

Children are born with a natural curiosity and desire for discovery. Daily life experiences provide children with countless opportunities to perceive, recognize, and make sense of the outside world. With each new activity, children build upon, alter and restructure their existing store of knowledge, actively continuing the process of discovery (Uyanık Balat, 2015).

Many science concepts first start to take shape during the preschool period (Lind, 1999; Kallery \& Psillos, 2001). Science helps develop the natural curiosity of children and leads them to make new discoveries (Eliason \& Jenkins 2003). According to Armga et al. (2002), science means discovery to young children, and the word 'discovery' refers to the active use of the five senses by the child. Science, which is an integral part of our daily lives, needs to be integrated into education programs in a meaningful way, emphasizing its connection with daily life (Eliason \& Jenkins 2003). Developing scientific thinking skills is one of the most important goals of science education (Armga et al., 2002). For children to learn basic scientific skills, teachers should be careful observers, know about the names of objects and relevant concepts, and be able to make comparisons when answering children's questions in science classes (Armga et al., 2002).

In the preschool period, children not only learn about science and nature-related concepts, they also start developing basic skills such as problem solving, scientific thinking and versatile thinking that will remain relevant for the rest of their lives (Güler \& B1kmaz, 2002). Science education provided at an early age allows children to recognize natural events, perceive relationships, make observations, interpret information, and acquire scientific process skills (Hamurcu, 2003).

In science education, the use of actual materials plays a very important role in the successful learning of scientific ideas and knowledge. For effective teaching of science topics, concrete materials that are appropriate for the level of education should be used in class activities (Osborne \& Freyberg, 1996; Şahin \& Y1ldırım, 1996). Materials also play a very important role in science education.

For an effective science education, children should start developing basic science concepts in the preschool period (Lind, 1999; Kallery \& Psillos, 2001), and teaching materials should be used in the teaching of science topics. Within this framework, this study aims to examine teaching materials created by prospective preschool teachers to be used in the teaching of science and nature topics. The study also aims to help prospective preschool teachers develop a better understanding of teaching materials, and contribute to the relevant literature.

\section{Methodology}

This study uses survey methodology, which aims to answer questions about a population or universe either by examining the whole population or a subset of the population, called a sample (Karasar, 2011). The sample group in this study consisted of 54 third-year students majoring in Preschool Teaching at the Faculty of Education of a public university in the northern part of Turkey, who volunteered to participate in the study. Purposive sampling was used to select the participants, which is used to create sample groups consisting of individuals 


\section{Al Macrothink}

Journal of Studies in Education

ISSN 2162-6952

2018, Vol. 8, No. 1

with similar characteristics (Cristensen, Johnson \& Turner, 2015). Prospective preschool teachers who participated in the study were divided into three-person groups, and asked to build teaching materials to be used in the teaching of science topics to preschool students. At the end of the practice, 2 open-ended questions have been asked to the teaching candidates to evaluate the factors that they pay attention while they develop the teaching material and the contribution of teaching material development process to them. Teaching materials prepared by the prospective teachers and they were examined using descriptive analysis. In descriptive analysis, the data collected are organized and summarized on the basis of pre-defined themes and presented with accompanying interpretation (Yıldırım \& Şimşek, 2011). As the names of teaching candidates have been hidden, they have been coded in the form of " $\mathrm{S}_{1}, \mathrm{~S}_{2} \ldots \ldots \mathrm{S}_{\mathrm{n}}$ ", the direct quotations from the students' answers have been included.

\section{Results}

\subsection{The Material Development}

Figures 1 through 11 show the teaching materials built by prospective preschool teachers to teach science topics.

Prospective teachers in Group 1 built teaching material that describe the stages of development of chicken, frogs and butterflies using pictures, which were designed as game cards for an ordering game. Figure 1 presents the teaching material showing chicks hatching from eggs and growing into adult chickens.
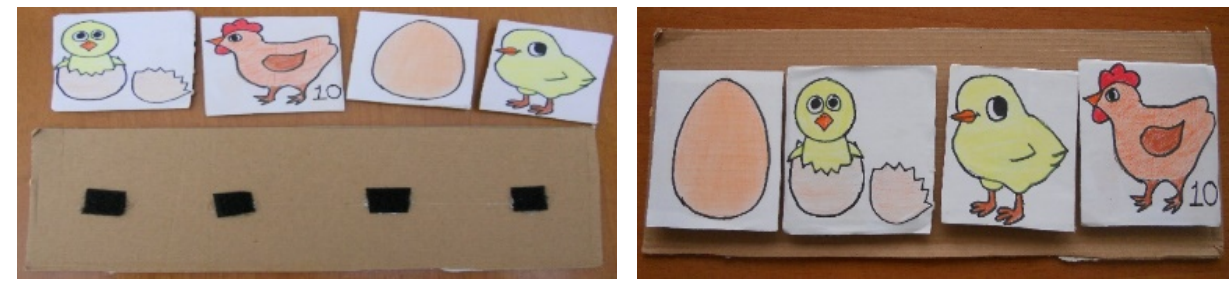

Figure 1. Teaching material prepared by group 1

Figure 2 presents a teaching material that describes the transformation of an egg, left by a female butterfly on a leaf, into a caterpillar that hangs itself upside down from a leaf stem, covers its body with a shell called a chrysalis (cocoon), develops a thick skin inside the cocoon, and transforms into an adult butterfly.
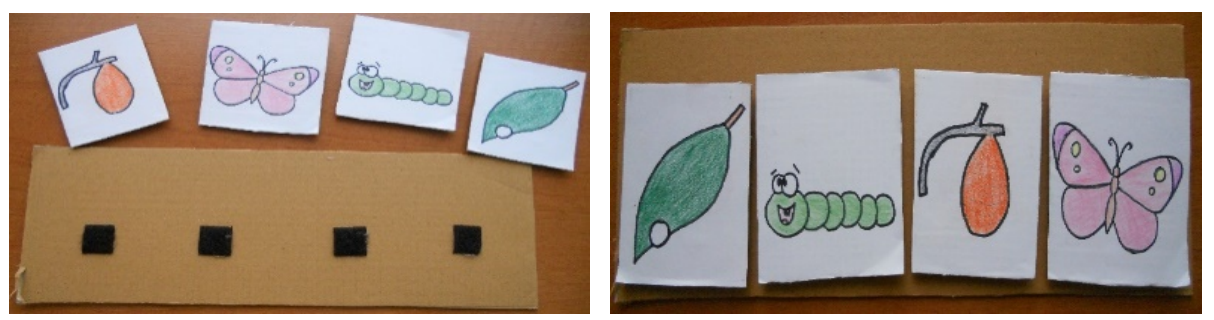

Figure 2. Teaching material prepared by group 1

Figure 3 presents a teaching material depicting the metamorphosis of a frog from an egg to a tadpole, to a young frog and finally to an adult frog. 

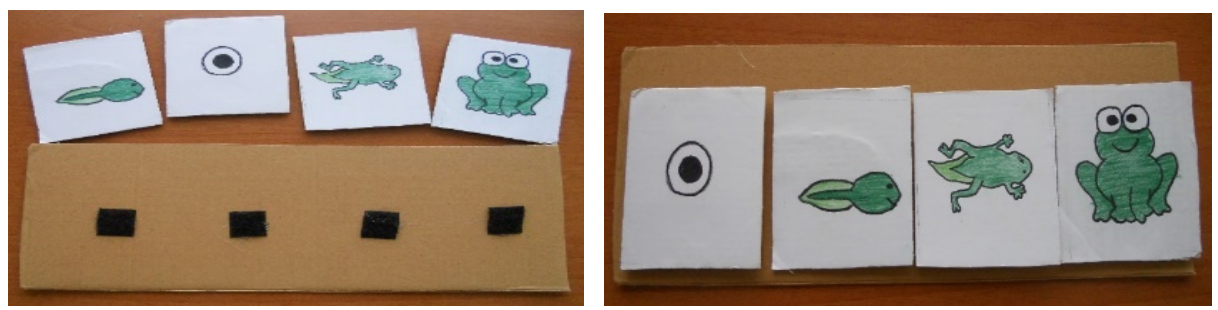

Figure 3. Teaching material prepared by Group 1

Prospective teachers in Group 2 designed a teaching material using four sheets of paper onto which they glued dried beans, peanut shells and various shapes of pasta (butterfly and fusilli), which can be used in the teaching of the stages of development of a butterfly. This teaching material is shown in Figure 4.

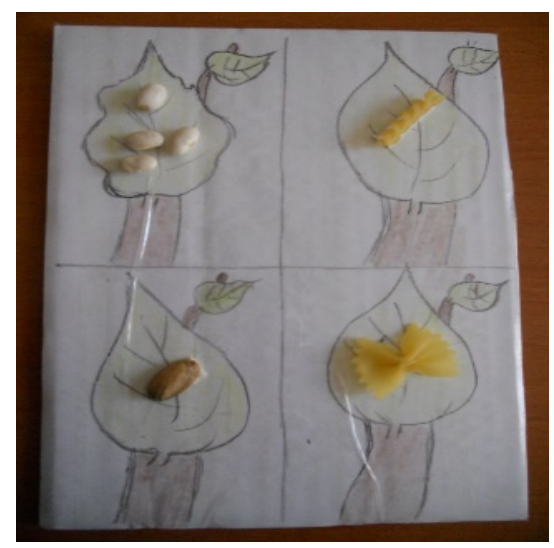

Figure 4. Teaching material prepared by Group 2

Prospective teachers in Group 3 designed teaching materials that can be used to teach the anatomical structure of caterpillars and butterflies. They designed a caterpillar puzzle to teach the anatomical structure of the caterpillar, and an origami butterfly to teach the anatomical structure of butterflies. This teaching material is shown in Figure 5.
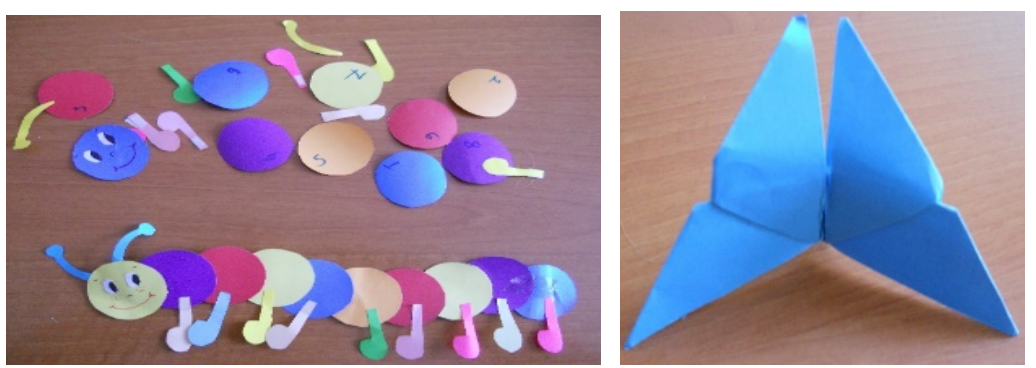

Figure 5. Teaching material prepared by Group 3

Prospective teachers in Group 4 developed teaching materials to be used in the teaching of the anatomical structures of frogs and dogs. Using colored cardboard, they built the figures of a frog and a dog with detachable body parts, such as legs, arms and tails, where the goal is for children to correctly attach these parts and learn about the anatomical structure of the animals in question. These teaching materials are shown in Figure 6. 

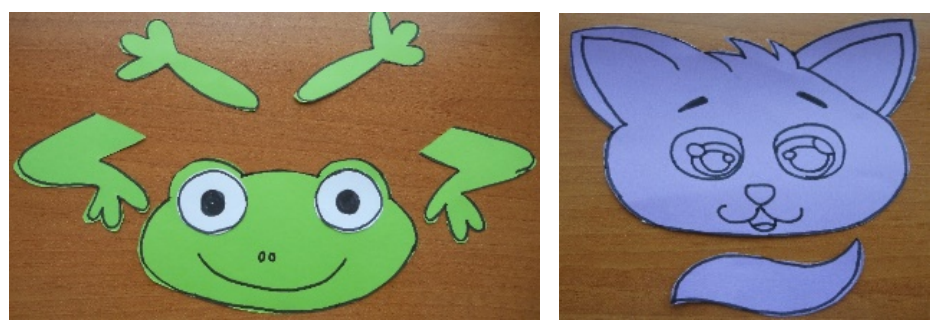

Figure 6. Teaching material prepared by Group 4

Prospective teachers in Group 5 developed a teaching material to teach about terrestrial animals. They developed teaching materials in the form of puzzles that aim to teach about different animals (rabbits, butterflies, elephants, lions, snails, turtles, cows, sheep, chickens, cows, cats, ants, bees, monkeys, bears, and ladybugs). These teaching materials, which are designed for children to have fun while learning about animals by building a whole animal from different parts, are shown in Figure 7.
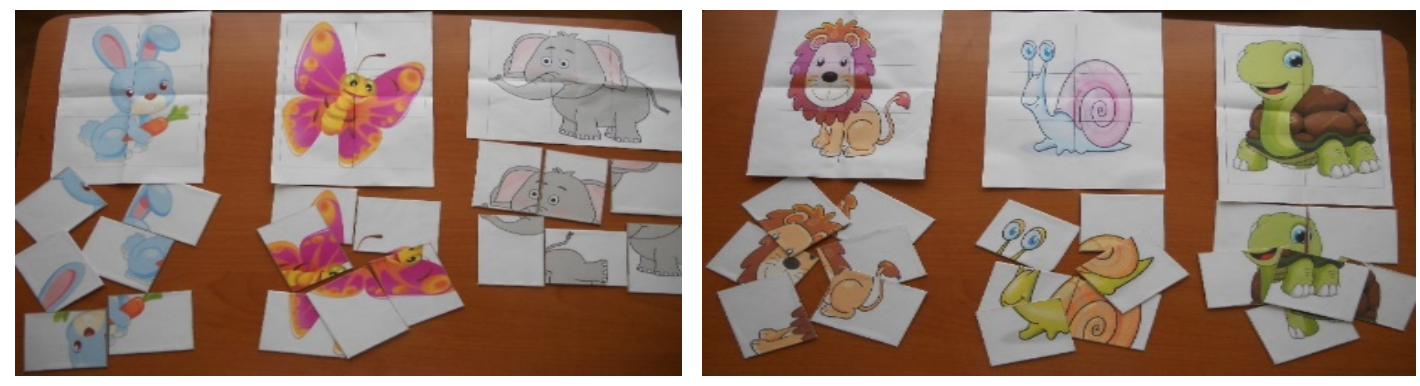

Figure 7. Teaching material prepared by Group 5

Prospective teachers in Group 6 developed a teaching material to teach the anatomical structure and characteristics of parrots. The teaching material uses a straw and a balloon to simulate parrot's flying, and strings attached to the sides to simulate flapping, with color papers added to emphasize the physical characteristics of the parrot. The parrot teaching material developed by prospective teachers is shown in Figure 8.

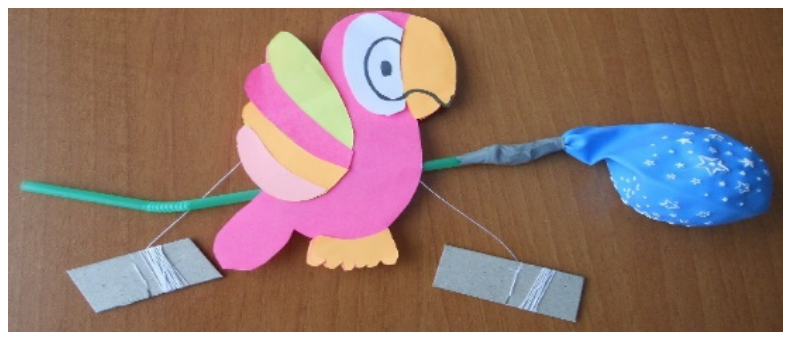

Figure 8 . Teaching material prepared by Group 6

Prospective teachers in Group 7 developed teaching materials to teach about poultry (chickens, roosters, turkeys, ducks and chicks) and their living environment. These teaching materials are shown in Figure 9. 

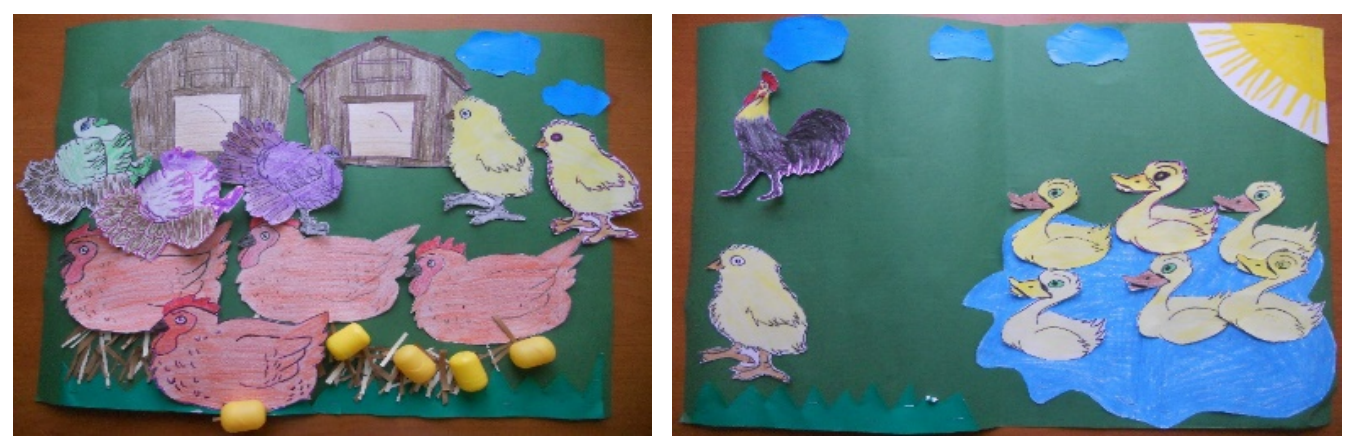

Figure 9. Teaching material prepared by Group 7

Prospective teachers in Group 8 developed a teaching material to teach about marine animals. It is aimed to animate the sea creatures of children's badges with this material. The teaching materials designed in the form of badges describing marine animals are shown in Figure 10.

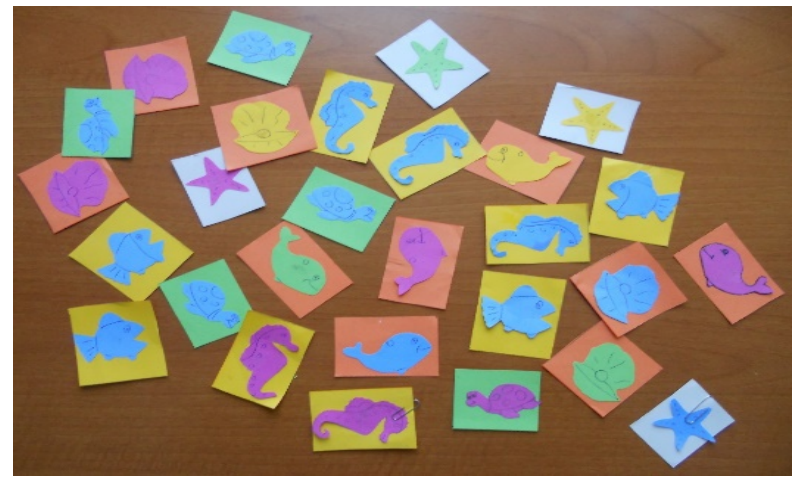

Figure 10. Teaching material prepared by Group 8

Prospective teachers in Groups 9 and 10 developed teaching materials to teach about fruits and vegetables.

Prospective teachers in Group 9 designed masks describing various fruits and vegetables. It is intended that children use masks to animate fruits and vegetables. Masks prepared by prospective teachers on the basis of shapes and colors of different fruits and vegetables are shown in Figure 11.

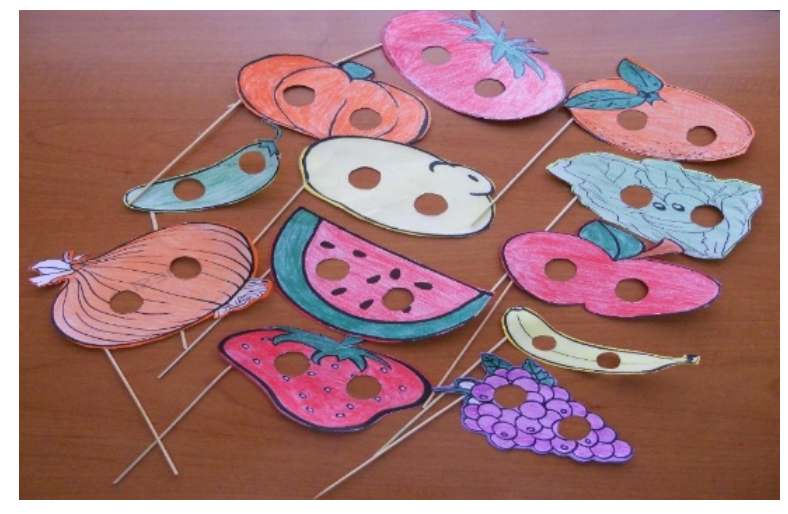

Figure 11. Teaching material prepared by Group 9

Prospective teachers in Group 10 designed teaching materials on the basis of the colors and 


\section{Macrothink}

shapes of various fruits and vegetables. These teaching materials are shown in Figure 12.

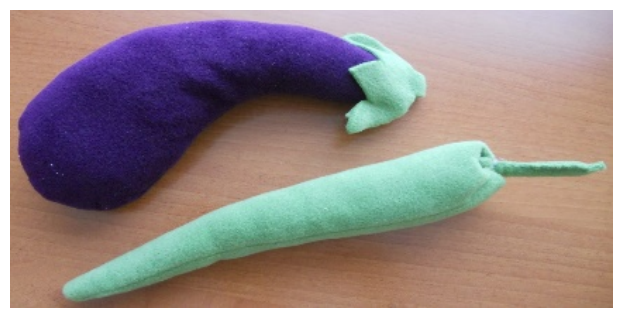

Figure 12. Teaching material prepared by Group 10

Prospective teachers in Group 11 designed a teaching material to teach about living and non-living things in our environment. They designed a painting in which living and non-living things children encounter in their daily lives (humans, dogs, roosters, birds, clouds, trees, houses, kennels, flowers) are brought together to form a whole, and children are encouraged to piece the puzzle together. This teaching material is shown in Figure 13.
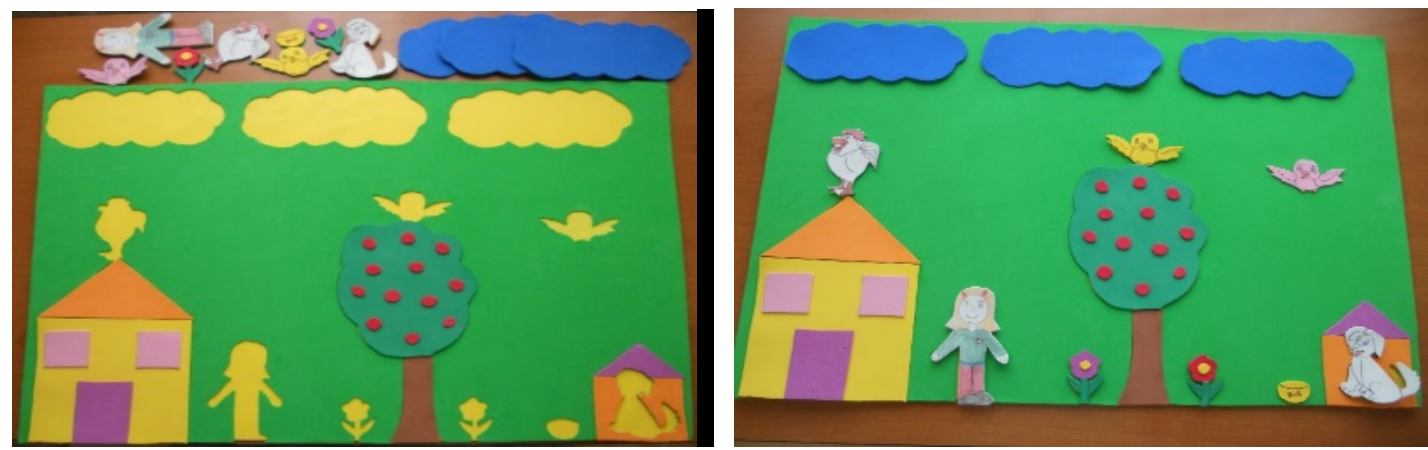

Figure 13. Teaching material prepared by Group 11

Prospective teachers in Group 12 developed teaching materials to teach the concepts of left and right. They have designed onions and garlic (which rhyme, respectively, with the Turkish words for right and left), to be used in an educational activity in which children will keep onions in their right hands and garlics in their left hands. This teaching material is shown in Figure 14.
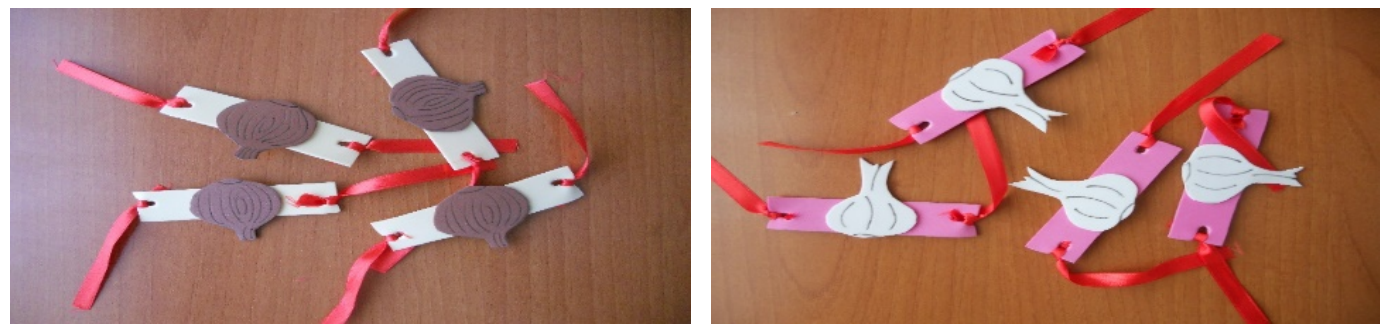

Figure 14. Teaching material prepared by Group 12

Prospective teachers in Group 13 developed a teaching material built using plastic bottles, cardboards, color paper and pasta. This teaching material was designed to teach major colors using a game, in which children pair color papers with pasta pieces of same color. This teaching material is shown in Figure 15. 


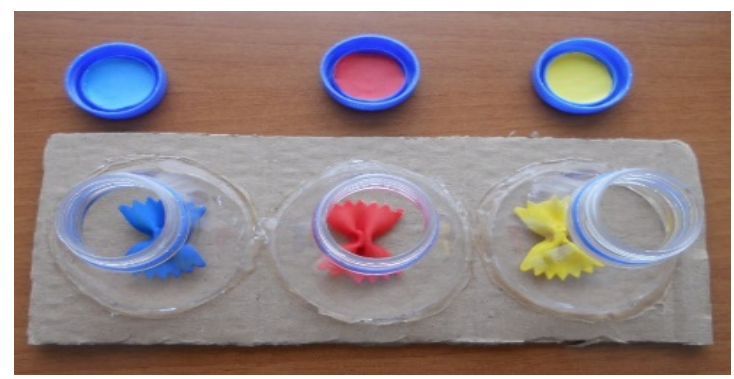

Figure 15. Teaching material prepared by Group 13

Prospective teachers in Group 14 developed teaching materials consisting of round cardboards that have the colors yellow and blue, red and blue, and yellow and red on their opposite sides, which then are revolved with the help of a string attached, making it possible to observe the secondary colors. These teaching materials, designed to teach the secondary colors that are created by mixing primary colors, are shown in Figure 16.
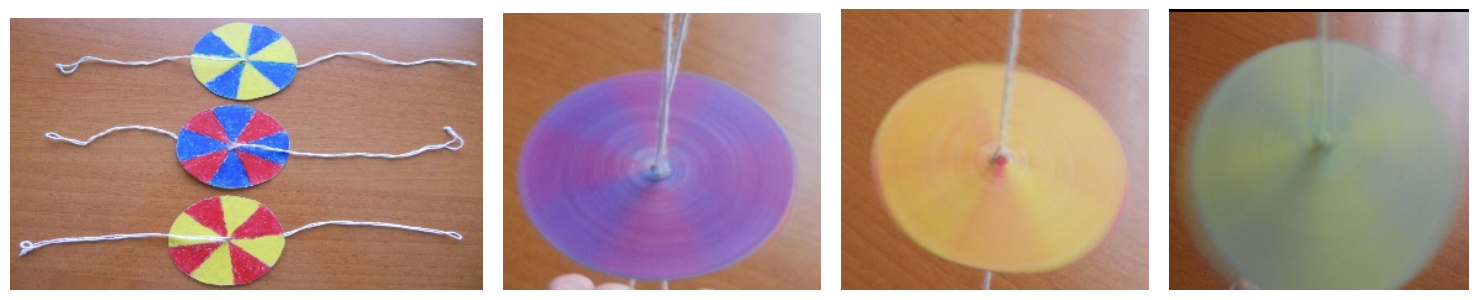

Figure 16. Teaching material prepared by Group 14

Prospective teachers in Group 15 developed teaching materials to teach about the concept of star and planets in the Solar System. Using rubber bands, they designed a game to teach the concept of star. They have also developed a teaching material Solar System in which planets made of colored cardboard on the basis of their relative sizes and other characteristics are suspended using strings, shown in Figure 17.
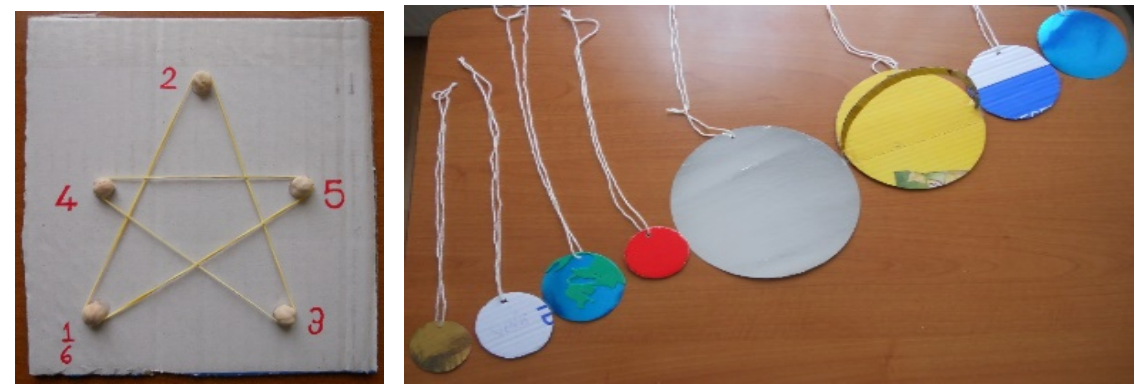

Figure 17. Teaching material prepared by Group 15

Prospective teachers in Groups 16 and 17 developed teaching materials intended to teach about the Solar System and the planets. Both groups designed teaching materials in the form of ordering games, Group 16 using cardboards and pictures of planets and Group 17 using colored play dough. Teaching materials prepared by prospective teachers in Groups 16 and 17 are shown in Figure 18 and Figure 19. 

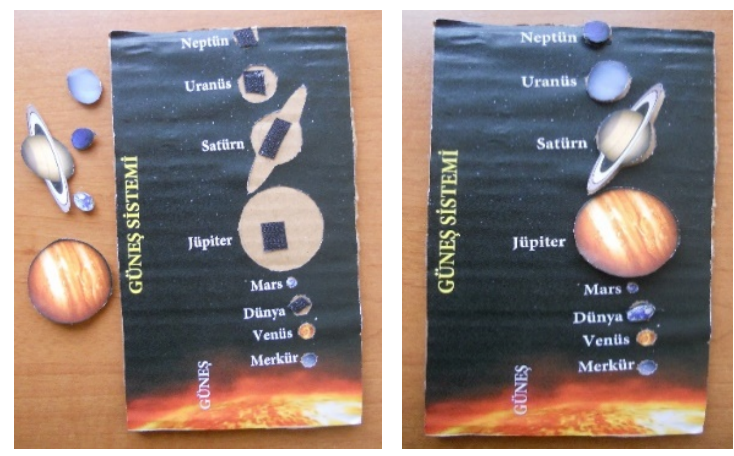

Figure 18. Teaching material prepared by Group 16
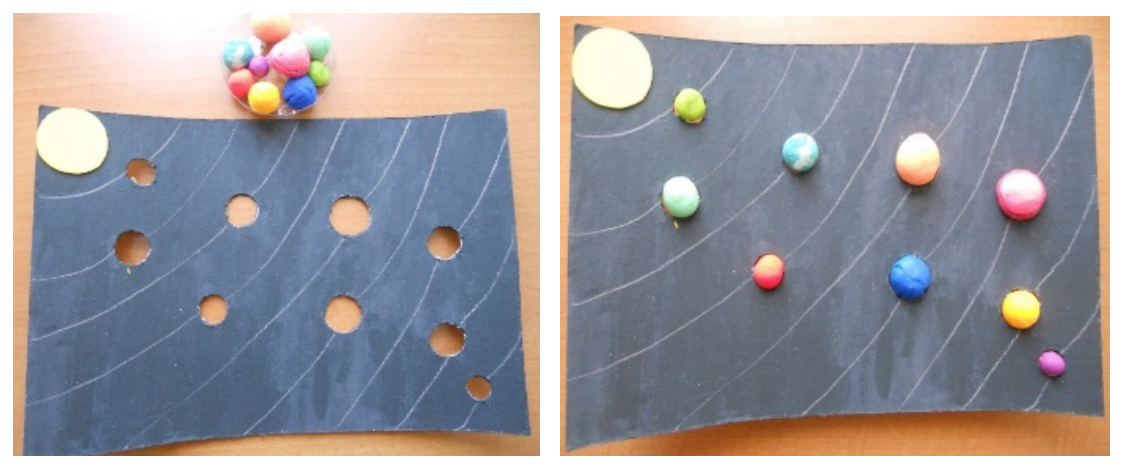

Figure 19. Teaching material prepared by Group 17

Prospective teachers in Group 18 designed human faces, fish, flowers and flower pots using plastic plates, used CDs, colored cardboards, used yogurt cups and carton cups, to teach about reuse and recycling. These teaching materials are shown in Figure 20.
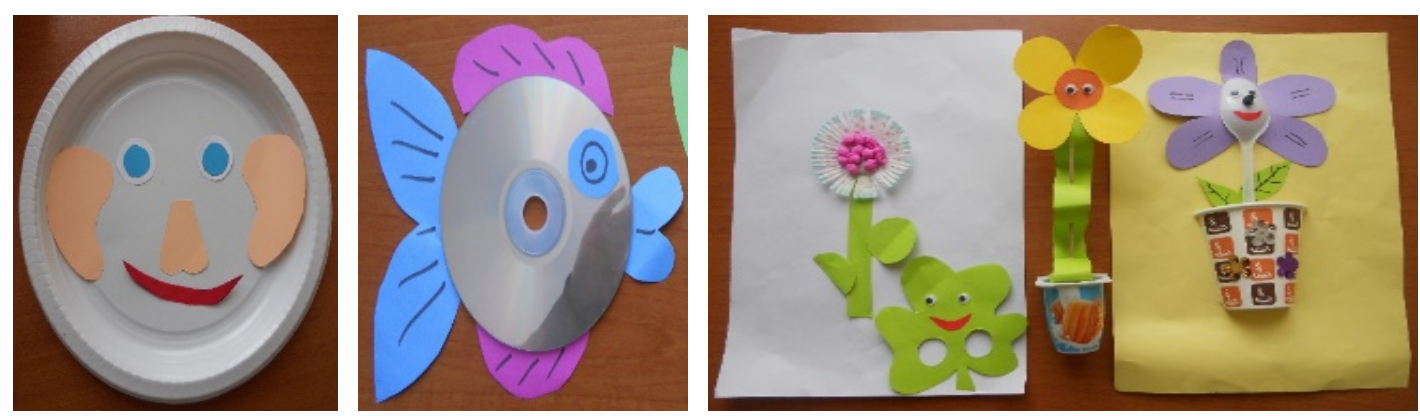

Figure 20. Teaching material prepared by Group 18

It was found that teaching materials designed by prospective teachers addressed a number of science topics. Table 1 reports the distribution of science topics addressed by the teaching materials developed by prospective teachers in this study. 
Table 1. Science topics addressed by the teaching materials

\begin{tabular}{lll}
\hline Main Category & Sub-Category & f \\
\hline \multirow{4}{*}{ Animals } & Terrestrial animals & 1 \\
\cline { 2 - 3 } & Marine animals & 1 \\
\cline { 2 - 3 } Stages of development of animals & Poultry and their living environment & 1 \\
\cline { 2 - 3 } & Stages of development of chickens & 1 \\
\cline { 2 - 3 } & Stage of metamorphosis in frogs & 2 \\
\cline { 2 - 3 } & Stage of transformation in butterflies & 1 \\
\hline \multirow{4}{*}{ Anatomical structures of animals } & Anatomical structure of caterpillars & 1 \\
\cline { 2 - 3 } & Anatomical structure of butterflies & 1 \\
\cline { 2 - 3 } & Anatomical structure of frogs & 1 \\
\cline { 2 - 3 } Colors & Anatomical structure of butterflies & 1 \\
\cline { 2 - 3 } & Anatomical structure of parrots & 1 \\
\hline Celestial bodies and the Solar & Primary colors & 1 \\
\cline { 2 - 3 } System & Secondary colors & 1 \\
\hline Reuse and recycling & The concept of a star & 1 \\
\hline Fruits and vegetables & The Solar System and the planets & 1 \\
\hline Living and non-living things & & \\
\hline Left and right & & \\
\hline
\end{tabular}

The materials used in science teaching materials developed by prospective teachers are given in Table 2. 
Table 2. Materials used by group

\begin{tabular}{cl}
\hline Group No & Materials \\
\hline 1 & Carton, Paper, Adhesive, Crayons \\
\hline 2 & Carton, Adhesive, Crayons, Beans, Macaroni (Fusilli, Farfalle), Peanut \\
\hline 3 & Color Paper, Clippers, Adhesive \\
\hline 4 & Color Paper, Clippers, Adhesive, Crayons \\
\hline 5 & Animal Pictures, Clippers \\
\hline 6 & Color Paper, Baloon, Carton, Pipette \\
\hline 7 & Construction Paper, Color Paper, Crayons, Plastic Egg \\
\hline 8 & Construction Paper, Color Paper, Clippers, Crayons \\
\hline 9 & Construction Paper, Clippers, Crayons, Splint \\
\hline 10 & Colored Fabric, Yarn, Needle, Cotton \\
\hline 11 & Colored Ethyl Vinyl Acetate, Clippers, Crayons, Paper \\
\hline 13 & Colored Ethyl Vinyl Acetate, Clippers, Crayons, Ribbon \\
\hline 14 & Plastic Bottle, Crayons, Macaroni (Farfalle), Carton \\
\hline 16 & Carton, Crayons, Rope \\
\hline 17 & Carton, Elastic, Crayons, Rope, Construction Paper, Pin \\
\hline 18 & Carton, Play Dough, Clippers, Crayons \\
\hline
\end{tabular}

The types of teaching materials developed by prospective teachers are given in Table 3 .

Table 3. Teaching Materials Type

\begin{tabular}{ll}
\hline Teaching Material Type & Figure No \\
\hline Ranking game & $1,2,3$ \\
\hline Pelmanism & 18,19 \\
\hline Track-whole game & $7,6,13,15$ \\
\hline Right-wrong game & 14 \\
\hline Modelling & $4,9,8,12,16,17,20$ \\
\hline Origami & 5 \\
\hline Dramatization & 10,11 \\
\hline
\end{tabular}

\subsection{The Evaluation of Material Development Process}

The frequency distributions belonging to the teaching candidates' answers for the question of "Which factors did you pay attention in developing the teaching material?" have been given at Table 4. 
Table 4. The significant factors to develop the teaching materials

The significant factors

Answering

frequency (f)

\begin{tabular}{ll}
\hline It should be suitable for the level of children. & 50 \\
\hline It should be suitable to the cognitive and motor development properties of children. & 48 \\
\hline It should be a material that the children will have fun while learning the subject. & 47 \\
\hline It should be developed with the materials which can be easily found. & 46 \\
\hline The proper teaching material for the certain subject should be developed. & 43 \\
\hline It should be colorful and remarkable & 41 \\
\hline It should be paid attention that the intangible concepts are materialized. & 34 \\
\hline The different techniques and methods should be used. & 32 \\
\hline The teaching material that the children can easily make it should be developed. & 27 \\
\hline The visuality should be paid attention & 25 \\
\hline
\end{tabular}

When Table 4 is reviewed, it is determined that the teaching candidates stated that they focused that the science teaching materials are suitable for the levels, cognitive and motor development properties of children, the materials are the one that the children will have fun while learning the subject, the materials can be easily found and they are suitable for the certain subject, they are the colorful and remarkable materials while the candidates developed the science teaching materials. Moreover, it has been seen that the teaching candidates focused that the intangible concepts are materialized, the different techniques and methods are used and the teaching materials which will be easily made by the children are developed and they focused on the visuality.

The direct quotations from the teaching candidates' answers on the question have been given as the following.

"I focus firstly on the level of children while I am preparing the teaching material. As they are the pre-school children, I try that they learn the subject as having fun in it after I design the games. I think that it is definitely important that it is colorful and remarkable because it is related to the pre-school children. I pay attention to develop the materials according to their development properties. I try to design the materials with the goods that I can find at every places in all the conditions. Because it is important to find the materials easily." $\left(S_{17}\right)$

"It should be suitable for the children's levels, cognitive and psychomotor development properties. Furthermore, the materials should be designed as to attract the children's attention, as colorful, funny and suitable for the subject which will be taught. The techniques and methods such as a game, drama, origami should be used. It should be designed with the goods that can be found easily." $\left(S_{21}\right)$

"The material should be designed by the children's level. Their development properties should be considered. The children should learn as having fun. Thus, the different techniques should be used. The colorful materials should be used as the materials are designed. The visuality is important. As the science subjects include the intangible concepts, the materials related to materialize the intangible concepts should be used." $\left(S_{38}\right)$ 
The frequency distribution belonging to the teaching candidates' answers for the question of "Do you evaluate the contribution of teaching material development process to you?" has been given at Table 5 .

Table 5. The teaching material development process

\begin{tabular}{lc}
\hline The contribution of teaching material development process & $\begin{array}{c}\text { Answering } \\
\text { frequency (f) }\end{array}$ \\
\hline $\begin{array}{l}\text { I think that my skill to develop the different materials related to the science subjects } \\
\text { has increased. }\end{array}$ & 52 \\
\hline I think that my creativity has increased as developing the materials. & 48 \\
\hline $\begin{array}{l}\text { I recognized that many different teaching materials can be developed with the use } \\
\text { of different materials. }\end{array}$ & 47 \\
\hline $\begin{array}{l}\text { I recognized that it is important to use the different techniques as developing the } \\
\text { materials. }\end{array}$ & 44 \\
\hline $\begin{array}{l}\text { I recognized that we can develop the materials of many goods that we use them in } \\
\text { our daily life. }\end{array}$ & 43 \\
\hline I understood that the objects around me can turn into a teaching material. & 40 \\
\hline My critical viewpoint developed. & 38 \\
\hline I recognized that I can design the teaching materials of the wastes. & 36 \\
\hline $\begin{array}{l}\text { I understood the importance to develop the materials with the goods which are } \\
\text { easily found in the daily life. }\end{array}$ & 35 \\
\hline I had nice time as developing the science teaching materials. & 15 \\
\hline I had a chance to use my knowledge on the pedagogical field. & 13 \\
\hline My self confidence increased. & 7 \\
\hline I felt myself as the beneficial one. &
\end{tabular}

When table 5 is reviewed, it is determined that the teaching candidates stated that they recognized that their skills to develop the different materials related to the science subjects increase, their creativity develops, many different teaching materials can be developed with the use of different materials, it is important to use the different techniques as developing the material, the material can be developed from many goods which are used in the daily life and the objects around them can turn into a teaching material. Furthermore, it is seen that they recognized that their critical viewpoints increase, they can develop the teaching material with the wastes, they understood the importance of developing a material from goods that they are easily found in the daily life and they stated that they have the nice time as developing the science material.

The direct quotations from the teaching candidates' answers for the question have been given as the following.

"Firstly, I saw that I can develop many different materials related to the teaching of science subjects in this process. My self-confidence increased about the material development. My creativity increased. I saw that many different materials will be designed with the use of different techniques. I understood that it is important to use the different method and techniques. Each 
object and goods around me can turn into a teaching material. I learnt to have the different viewpoint on everything around me." $\left(S_{23}\right)$

"I think that my creativity and critical viewpoint develop. Moreover, I used the different method and techniques while I was developing the materials as having a chance to use my knowledge on the pedagogical. I understood that it is important that the different method and techniques are used. I can say that I can say that I understood the importance of designing the material of the wastes that we use and throw them into the rubbish in our daily life. I think that it is important to use the goods which are easily found as developing the material. You have a nice time really and feel yourself as beneficial while developing the material." $\left(S_{47}\right)$

\section{Conclusion}

This study found that prospective teachers develop teaching materials on a range of science topics. They have developed teaching materials to be used in the teaching of animals, stages of development of animals, their anatomical structures, and fruits and vegetables. In addition, they developed fun teaching materials that could get the attention of children, on primary and secondary colors, celestial bodies and the Solar System, reuse and recycling, living and non-living things, and the concepts of left and right. Prospective teachers designed teaching materials in the form of jigsaw puzzles that would help children develop a better perception of parts and wholes. In their teaching materials, prospective teachers took care to build colorful and fun teaching materials designed to attract children's attention, using materials that are easy to find in daily life.

As a result of the research, it is determined that the teaching candidates gave importance as developing the sciences teaching materials that they are suitable for the children's level, cognitive and motor development properties, they are the teaching material that the students will have fun as learning the subject, the materials which can be easily found are used and they are suitable for the certain subject, they are the teaching materials that are colorful, remarkable and the children will have fun as learning the subjects. Moreover, it is seen that the teaching candidates paid attention to materialize the intangible concepts, to use the different technique and methods and to develop the teaching materials that the children can easily make, and they paid attention on the visuality.

Hence, Hurwitz and Day (1995) state that the teachers need to be sensitive on the materials and techniques which will be used in consideration with the children's development levels.

The research results reveal that the teaching candidates recognized that their skills to develop the different materials related to the science subjects increase, their creativity develops, many different teaching materials can be developed with the use of different materials, it is important to use the different techniques as developing the material, they can develop the material of many goods which are used in the daily life and the objects around me can turn into a teaching material. Similarly, Ersoy (2006) states that the process develops the creativity of most of candidates in his research that he searched the views of the teaching candidates related to evaluation which is based on the portfolio. Moreover, it is determined that they recognized that their critical viewpoints develop and they can design the teaching materials 
with the wastes. Hence, Drew (1995) states that the suitable usage of waste materials can become a rich source which stimulate the creative thinking. It contributes to the development of abstract thought and imagination in the process of transforming the waste materials into the different forms that the child attributes the different meanings to the object (Eckhoff \& Spearman, 2009; Gandini \& Kaminsky, 2005).

Children learn to like or dislike science at school (Koballa \& Crawley, 1985). Thus, teachers have an important role to play in helping preschool students develop positive attitudes towards science (Davies \& Howe, 2003). If they develop positive attitudes towards science and have successful experiences participating in science activities, children will develop a long-term interest in science and enjoy learning science topics. Use of teaching materials in science education is important for drawing and retaining students' attention, for making science fun, and for achieving long-term and meaningful learning.

Given the importance of science education in early childhood, preschool teachers are expected to have a good grasp of a diverse range of complex science topics (Kallery, 2004). Because preschool science education plays an important role in developing positive attitudes towards science among children, preschool teachers should be taught the necessary knowledge and skills to conduct science activities in the most effective manner possible. For preschool teachers to acquire these skills, undergraduate materials development courses should cover science materials for teaching, and include activities designed to improve prospective teachers' material development skills for science activities. For the provision of a high quality science education and development of lifelong positive attitudes towards science, preschool teachers should acquire the necessary skills to develop fun, harmless, and eye-catching teaching materials, appropriate for the education level of their students. It is also believed that visualization in science lessons is important for children to visualize science subjects in their minds. Examples of material presented in this study may give pre-school teachers and preschool teacher candidates' ideas on how to improve their material. However, it is thought that pre-school children will have opportunities to learn by doing-living.

\section{References}

Armga, C., Dillon, S., Jamsek, M., Jolley, P., Morgan, E.L., Peyton, D., \& Speranza, H. (2002). Tips for helping children do science. Texas Child Care, 26(3), 2-7.

Christensen, L.B., Johnson, R.B., \& Turner, L.A. (2015). Araştırma yöntemleri desen ve analiz (Research methods, design, and analysis). In Ahmet Alpay (Translation Ed.). Ankara: An1.

Davies, D., \& Howe, A. (2003). Teaching science and design and technology in the early years. London: David Fulton Publishers.

Drew, W.F. (1995). Recycled Materials: Tools For Creative Thinking. Scholastic Early Childhood Today, 9(5), 36-43.

Eckoff, A., \& Spearman, M. (2009). Rethink, reimagine, reinvent: the Reggio Emilia Approach to incorporating reclaimed materials in children's artworks. Art Education, 62(2), $10-16$. 
Eliason, C., \& Jenkins, L. (2003). A practical guide to early childhood curriculum. Upper Saddle River, NJ: Merril/Prentice Hall.

Ersoy, A.F. (2006). Öğretmen adaylarının gelişim dosyasına dayalı değerlendirmeye ilişkin görüşleri. İlköğretim Online, 5(1), 85-95.

Gandini, L., \& Kaminsky, J. (2005). Remida, the creative recycling center in Reggio Emilia: An interwiev with Elena Giacopini, Graziella Brighenti, Arturo Bertoldi, and Alba Ferrari. Innovations in Early Education, 12(3), 1-13.

Güler, D., \& Bıkmaz, F.H., (2002). Ana sınıflarda fen etkinliklerinin gerçekleştirilmesine ilişkin öğretmen görüşleri. Eğitim Bilimleri ve Uygulama, 1(2), 249-267.

Hamurcu, H. (2003). Okul öncesi eğitimde fen bilgisi öğretimi 'Proje Yaklaşımı'. Ĕgitim Araştırmaları, 4(13), 66-72.

Hurwitz, A., \& Day, M. (1995). Children and their art. USA: Harcourt Brace College Publishers.

Kallery, M., \& Psillos, D. (2001). Pre-school teachers' content knowledge in science: Their understanding of elementary science concepts and of 1ssues raised by children's questions. International Journal of Early Years Education, 9(3), 165-177. https://doi.org/10.1080/09669760120086929

Kallery, M. (2004). Early years teachers late concerns and perceived needs in science: An exploratory study. European Journal of Teacher Education, 27(2), 147-165. https://doi.org/10.1080/026197604200023024

Karasar, N. (2011). Bilimsel araştırma yöntemleri. (22. bask1). Ankara: Nobel.

Koballa, J.R., \& Crawley, F.E. (1985). The influences of attitude on science teaching and learning. School $\quad$ Science $22-232$. https://doi.org/10.1111/j.1949-8594.1985.tb09615.x

Lind, K.K. (1999). Science in early childhood: developing and acquiring fundamental concepts and skills. In American Association for the Advancement of Science (AAAS). Dialogue on early childhood science, mathematics, and technology education. Washington, DC: AAAS, pp. 73-83.

McKean, B. (2001). Concerns and considerations for teacher development in the arts. Arts Education Policy Review, 102(4), 27-32. https://doi.org/10.1080/10632910109600005

Osborne, R., \& Freyberg, P. (1996). Learning in science: The implications of children' science. Portsmouth, NH: Heinemann.

Şahin, T., \& Yıldırım, S. (1996). Öğretim teknolojileri ve materyal geliştirme. Ankara: Anı.

Uyanık Balat, G. (2015). “Fen nedir ve çocuklar feni nasıl öğrenir?”. In B. Akman, G. Uyanık Balat, T. Güler (Eds). Okul öncesi dönemde fen eğitimi (3.bask1). Ankara: Pegem Akademi.

Yıldırım, A., \& Şimşek, H. (2011). Sosyal bilimlerde nitel araştırma yöntemleri. Ankara: Seçkin. 